Józef Kus

(Lublin)

\title{
Jarosławski epizod dziejów Trybunału Koronnego Lubelskiego - 1711 rok
}

aвstrakt: Lublin był siedzibą Trybunału Koronnego przez ponad 200 lat i w ciągu całej swojej historii sądził tylko raz w innym mieście, mianowicie w Jarosławiu w 1711 r. Wyjazdowa kadencja sądu rozpoczęła się w kwietniu, a skończyła w grudniu tego roku. Przez ten czas miasto i obradujący deputaci byli świadkami wielu wydarzeń. Między innymi w czerwcu $1711 \mathrm{r}$. miało tu miejsce spotkanie cara Piotra I z królem Augustem II, odbyła się też rada senatu. Podczas pobytu car trzymał do chrztu syna mieszczan jarosławskich, Jana i Marianny Gruszewiczów. O samej sesji Trybunału Koronnego i o rozpatrywanych na niej sprawach nic nie wiemy, ponieważ akta trybunalskie kadencji wyjazdowej uległy zniszczeniu.

sŁowa KLuczowe: Trybunał Koronny, sąd, Lublin, Jarosław, wielka wojna północna, pozostałość aktowa.

Utworzony w roku 1578 z woli króla Stefana Batorego na sejmie walnym warszawskim Trybunał Koronny (Iudicium Ordinarium Generale Tribunalis Regni) był najwyższym sądem szlacheckim w przedrozbiorowej Rzeczypospolitej. Sądził w Piotrkowie i Lublinie. Lublin był siedzibą Trybunału przez ponad 200 lat (ostatnia sesja odbyła się w 1794 r.) i w ciągu całej swojej historii sądził tylko raz w innym mieście, mianowicie w Jarosławiu. Tego epizodu dotyczy niniejszy artykuł.

Pierwsze dziesięciolecie XVIII w. upłynęło w Rzeczypospolitej pod znakiem rozstroju wewnętrznego, zniszczeń wojennych, rozkładu życia gospodarczego. Przez kraj przelewały się obce wojska, które uczyniły z niego 
olbrzymie pole bitewne. Partie zwolenników Wettyna i Leszczyńskiego rujnowały posiadłości przeciwników. Wydzierano kontrybucje pieniężne, rabowano żywność i dobytek, palono domostwa, mordowano bezbronnych. Przewlekłe kampanie, marsze i kontrmarsze, ustawiczne przechody wojsk, które objęły całą bez wyjątku Rzeczpospolitą, dokonywały większych spustoszeń niż najzaciętsze bitwy ${ }^{1}$.

W dwunastym roku trwania wielkiej wojny północnej (1700-1721) życie w trybunalskim Lublinie zdawało się wracać do normalności. Po zwycięstwie połtawskim cara Piotra I (1709 r.) wojna przeniosła się poza granice kraju ${ }^{2}$. Wraz z wojną przyszła jednakże pandemia dżumy, przywleczona z Turcji. W latach 1704-1705 wyludniła ona Lwów, stąd przez Jarosław, Tarnów, Zamość i Opatów objęła całą Polskę. W 1708 r. dotarła do Lublina, gdzie srożyła się przez następne lata ${ }^{3}$. Pod koniec 1710 r. zaraza ustała i nic nie zapowiadało jej nawrotu.

Na początku $1711 \mathrm{r}$. bulwersował lublinian proces grabarzy oskarżonych o szerzenie dżumy. Domniemani sprawcy zarazy po wymyślnych torturach skazani zostali na obcięcie rąk i głów, które wystawione zostały na palach „na rozstajach dróg", ku przestrodze innym ${ }^{4}$.

Przystąpiono do odbudowy domów, które uległy zniszczeniu w wyniku pożaru w czerwcu 1710 r. $^{5}$ W kwietniu po niedzieli przewodniej odbyła się uroczysta reasumpcja lubelskiej kadencji Trybunału Koronnego, trzeciej już po trzyletniej przerwie w latach 1706-1708, spowodowanej zawirowaniami wojennymi ${ }^{6}$.

${ }^{1} \mathrm{~J}$. Gierowski, Między saskim absolutyzmem a złotą wolnością. Z dziejów wewnętrznych Rzeczypospolitej w latach 1712-1715, Wrocław 1953, s. 9.

${ }^{2}$ G. Hyczko, Działania wojenne trzeciej wojny pótnocnej (1700-1721) w województwie lubelskim, „Rocznik Lubelski” T. 7, 1965, s. 90.

${ }^{3}$ A. Karpiński, $W$ walce $z$ niewidzialnym wrogiem. Epidemie chorób zakaźnych $w$ Rzeczypospolitej w XVI-XVIII w. i ich następstwa demograficzne, społeczno-ekonomiczne i polityczne, Warszawa 2000, s. 71-72.

${ }^{4}$ Z. Klukowski, Sprawa o szerzenie dżumy w Lublinie (Odczyt wygłoszony na III Zjeździe Polskich Historyków i Filozofów Medycyny w Poznaniu dnia 19 października 1926 r.), „Archiwum Historii i Filozofii Medycyny oraz Historii Nauk Przyrodniczych” T. 6, z. 1, Poznań 1927.

${ }^{5}$ H. Gmiterek, Lublin w stuleciach XVII i XVIII, [w:] Lublin. Dzieje miasta. T. I: Od VI do końca XVIII wieku, red. R. Szczygieł, H. Gmiterek, P. Dymmel, Lublin 2008, s. 121.

${ }^{6}$ K. Niesiecki, Herbarz Polski, Lipsk 1839-1846, s. 382. Próby reasumpcji Trybunału, po wymuszonej abdykacji Augusta II, podejmowane były w tym czasie zarówno przez jego zwolenników, jak i stronników Stanisława Leszczyńskiego. Zob. J. Burdowicz-Nowicki, Piotr I, August II i Rzeczpospolita 1697-1706, Kraków 2010, s. 720-721. 
Ufundowanie Trybunału, czyli rozpoczęcie sesji, było jednym z ważniejszych wydarzeń w miastach trybunalskich. Zainteresowani procesami ściągali ze stronnikami, magnaci z wojskami nadwornymi w celu wywarcia presji na przeciwników, a w razie potrzeby - aby nie dopuścić do zapadnięcia niewygodnego dla nich wyroku. Doszło do tego, że w omawianym okresie każde rozpoczęcie Trybunału było wydarzeniem niejednokrotnie ważniejszym od obrad sejmowych ${ }^{7}$. Na sesje trybunalskie do Lublina zjeżdżała szlachta z całej Małopolski, Podlasia, Wołynia, Podola i Ukrainy.

Tym razem frekwencja była niska. Trybunał - według świadectwa pamiętnikarza Wawrzyńca Franciszka Rakowskiego - zaczął sesję pod przewodnictwem wicemarszałka, z udziałem 4 deputatów duchownych i tylko 13 świeckich. „Szlachty mała liczba, dlatego kondemnują" - podkreślał pamiętnikarz ${ }^{8}$.

Krótki okres względnego spokoju w mieście przerwał nagły nawrót zarazy. Podjęto zwykłe w takich okolicznościach środki zaradcze: zamknięto bramy przed przybyszami, a władze miejskie ewakuowały się na wieś, pozostawiając burmistrza

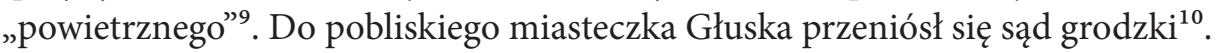

Nie po raz pierwszy epidemie przerywały kadencję lubelską Trybunału Koronnego, limitowano je z tego powodu już w latach 1588, 1641 i $1652^{11}$. Przed taką perspektywą stanęli deputaci i tym razem, nie rozjechali się jednak, by powrócić do Lublina po ustaniu zarazy, lecz wybrali inne rozwiązanie. Skorzystali mianowicie z zaproszenia właścicieli miasta Jarosławia, aby w tym znanym centrum handlowym kontynuować przerwane sądy.

Należy dodać, iż w ogóle Trybunał w 1710/11 r. zaczynał się pod nieszczęśliwą gwiazdą z powodu zarazy. Kadencja piotrkowska rozpoczęła się 6 X 1710 r. nie

7 Z. Kaczmarczyk, B. Leśnodorski, Historia państwa i prawa Polski. T. II, Warszawa 1966, s. 264-265; W. Witkowski, Trybunał Koronny w Lublinie, [w:] Spojrzenia w przeszłość Lubelszczyzny, red. K. Myśliński, A. A. Witusik, Lublin 1974, s. 88.

${ }^{8}$ „Z Lublina 26 IV: trybunał koronny pod przewodnictwem J[ego] M[ość] Pana Chwaliboga podskarbiego krakowskiego wicemarszałka, w towarzystwie czterech deputatów duchownych i 13 świeckich, odprawia się zwykłym zwyczajem”. Zob. W. F. Rakowski, Pamiętnik wielkiej wojny pótnocnej, Warszawa 2002, s. 143. W rzeczywistości Stanisław Walerian Chwalibóg nie był podskarbim, lecz podstolim i wiceregentem gr. krakowskim. Z tymi urzędami podpisywał się pod dekretami (Archiwum Narodowe w Krakowie, Archiwum Sanguszków, Teki Rzymskie, sygn. LVII/69, s. 501, 517).

${ }^{9}$ Zazwyczaj do wsi miejskich Konopnicy i Bystrzycy. Zob. A. Karpiński, dz. cyt., s. 228.

${ }_{10}$ Archiwum Państwowe w Lublinie (dalej APL), Księgi grodzkie lubelskie (dalej Kgl), Relacje, sygn. 199, s. 218, 225, 278, 281, 433.

11 E. Otwinowski, Pamiętniki do panowania Augusta II, Poznań 1838, s. 196; A. Karpiński, dz. cyt., s. 289 . 
w Piotrkowie „zarażonym powietrzem”, lecz w pobliskim Witowie, gdzie po mszy w miejscowym kościele reasumpcja odbyła się w polu pod namiotami. Wkrótce po obiorze marszałka Trybunał zalimitowano na 12 I. Zdaje się, że rzeczywiście potem zaraza nieco odpuściła, gdyż wznowienie sądów w Piotrkowie w styczniu odbyło się bez większych problemów, podobnie jak reasumpcja w Lublinie 13 IV 1711 r. ${ }^{12}$ Jarosławski epizod dziejów Trybunału Koronnego nie posiada szerszego odbicia w literaturze. Najwcześniejszy przekaz o nim zamieścił w swoim opisie geograficzno-statystycznym Galicji (wyd. w Przemyślu w 1786 r.) geograf, heraldyk i bibliofil Ewaryst Andrzej Kuropatnicki przy opisie Jarosławia, z mylną jednak datą: „Sądził się tu trybunał w r. 1724”13.

Właściwą datę i przyczynę przeniesienia Trybunału podał w pierwszej monografii Jarosławia Franciszek Siarczyński (wyd. we Lwowie w 1826 r.): „Tegóż roku 1711 gdy morowa zaraza w Lublinie szerzyła się, do Jarosławia przeniesiony trybunał koronny od d. 13. lipca odsądził zwykłey kadencji sprawy"14.

Od czasu ukazania się wzmiankowanej pracy, chociaż powstało niemało pozycji poświęconych przeszłości Jarosławia, wiedza nasza o tym ważnym w dziejach miasta wydarzeniu nie powiększyła się ani odrobinę. Spostrzeżenia na ten temat w nich zawarte sprowadzają się w zasadzie do powtórzenia informacji za Siarczyńskim.

Próżno też szukać wzmianki o tym epizodzie w pracach dotyczących Trybunału Koronnego Lubelskiego ${ }^{15}$. Jedynie Maria Stankowa, autorka artykułu nt. pozostałości aktowej najwyższego sądu szlacheckiego w lubelskim Archiwum Państwowym, zaznacza: „Teczka 4 zawiera zarządzenia dotyczące limitów spraw, listy odroczne i przeniesienia w r. 1711 sesji Trybunału z Lublina do Jarosławia z powodu morowej zarazy"16. Żeby docenić doniosłość opisywanego wydarzenia dla Jarosławia, przypomnieć należy, czym był Trybunał Koronny. Utworzony został w roku 1578 na sejmie walnym warszawskim, gdy król Stefan Batory, jako iudex supremus, zrzekł się dotychczasowych uprawnień najwyższego sędziego na rzecz stanowego

12 S. Bielicki, Sprawiedliwość nieśmiertelnej sławy, korrupcyi i zarazie niepodległa, albo kazanie przy inauguracyi Głównego Trybunału, w kościele ww. oo. premonstratensów, podczas zarażonego powietrzem Piotrkowa, w Witowie przywitana..., Częstochowa 1710, s. nlb.; W. Kuczyński, Pamiętnik 1668-1737, oprac. J. Maroszek, Białystok 1999, s. 41-42.

${ }^{13}$ E. A. Kuropatnicki, Geografia albo dokładne opisanie Królestw Galicji i Lodomerii, Lwów 1858 , s. 38.

${ }^{14}$ F. Siarczyński, Wiadomość historyczna i statystyczna o mieście Jarosławiu, Lwów 1826, s. 112.

${ }^{15}$ Najaktualniejszą bibliografię „trybunalską” zamieszcza w swojej pracy W. Bednaruk, Trybunat Koronny. Szlachecki sąd najwyższy w latach 1579-1794, Lublin 2008, s. 311-321.

${ }^{16}$ M. Stankowa, Ocalałe fragmenty akt Trybunału Koronnego Lubelskiego w Wojewódzkim Archiwum Państwowym w Lublinie, „Archeion” T. 40, 1964, s. 120. 
sądu szlacheckiego. Na miejsce sądów wyznaczono Piotrków i Lublin. Sądzili w nim reprezentanci szlachty i duchowieństwa - deputaci. W Piotrkowie rozsądzano sprawy z terenu Wielkopolski i Mazowsza, w Lublinie rozstrzygane były sprawy z województw małopolskich: krakowskiego, sandomierskiego, ruskiego, podolskiego, podlaskiego, wołyńskiego, bełskiego, lubelskiego, a od 1590 r.: kijowskiego, bracławskiego i czernihowskiego. Na czele trybunału stał obieralny marszałek. Deputatom duchownym przewodził prezydent. Tę godność z reguły piastował przedstawiciel kapituły gnieźnieńskiej. Trybunał Koronny rozpatrywał apelacje w sprawach cywilnych od wyroków sądów niższych instancji (ziemskich, grodzkich, podkomorskich, komisarskich, wiecowych oraz sądów ultimae instantiae, działających w niektórych województwach dla odciążenia sądu królewskiego i sejmowego). Rozstrzygał także sprawy starostów i innych urzędników grodzkich o wykorzystywanie kompetencji do celów prywatnych lub ich nadużywanie, zwłaszcza przy egzekwowaniu wyroków. W zakres uprawnień Trybunału wchodziła także jurysdykcja niesporna, a dokonane przed nim zapisy, protestacje czy relacje miały pełną moc prawną. W Piotrkowie sądy rozpoczynały się na podstawie konstytucji sejmowej z 1611 r. od świętego Franciszka (4 X). Ich koniec wyznaczono na Niedzielę Palmową. Sesje w lubelskim ratuszu zaczynały się w poniedziałek po niedzieli przewodniej i trwały do wyczerpania spraw. Po reformach Trybunału w 1641, a zwłaszcza w 1669 i 1676 r., konkretnie wyznaczono limitę - zakończenie Trybunału w Lublinie na wigilię św. Tomasza (21 XII). Do miasta zjeżdżało kilkudziesięciu deputatów (na początku XVIII w. 53 świeckich i 14 duchownych; po zmianach w latach 1726 i 1736 pozostało 51 świeckich i nadal 14 duchownych), palestra i inni urzędnicy. Trybunał był sądem o największym znaczeniu w państwie i mimo licznych niedoskonałości, na tle pogłębiających się deformacji w systemie wewnętrznym Rzeczypospolitej, zwłaszcza w czasach saskich, zaczął być określany jako „Najjaśniejszy”, który to tytuł przysługiwał do tej pory tylko królowi ${ }^{17}$.

Według opinii historyka prawa, autora najnowszej monografii najwyższego sądu, „Trybunał Koronny to szczytowe osiągnięcie rodzimej myśli politycznej i jedna z najważniejszych instytucji w państwie"18.

${ }^{17}$ O. Balzer, Geneza Trybunału Koronnego. Studium z dziejów sądownictwa polskiego XVI wieku, Warszawa 1886; Z. Mayer, Wizerunek Trybunału Koronnego. Studium prawno-obyczajowe, Lwów 1929; W. Witkowski, Trybunat Koronny w Lublinie - organizacja i funkcjonowanie, [w:] 40o-lecie utworzenia Trybunału Koronnego w Lublinie. Materiały z sesji naukowej w dniu 20 XI 1978, red. H. Groszyk, Lublin 1982, s. 59-71.

${ }^{18}$ W. Bednaruk, dz. cyt., s. 6. 
Jarosław, do którego przeniósł się Trybunał, był w tym czasie współwłasnością hetmana wielkiego koronnego Adama Mikołaja Sieniawskiego i jego żony Elżbiety z Lubomirskich oraz ordynata ostrogskiego i starosty sandomierskiego Aleksandra Dominika Lubomirskiego. Mimo iż ucierpiało w pierwszych latach wojny ${ }^{19}$, miasto zachowało pewne walory obronne. I tu przystąpiono, podobnie jak w Lublinie, do usuwania zniszczeń wojennych. Z poważniejszych przedsięwzięć budowlanych $\mathrm{w}$ tym okresie wspomnieć należy o budowie klasztoru i kościoła reformatów, fundacji mieszczanina Antoniego Kwolka i łowczego kijowskiego Franciszka Zawadzkiego, jak też o odbudowie spalonego w 1707 r. kościoła Najświętszej Marii Panny „w Polu”20. Ważne miejsce zajmował Jarosław w organizacji samorządu Żydów Korony, gdyż od lat 8o. XVII w. zbierał się tutaj regularnie tzw. Sejm Czterech Ziem, stanowiący reprezentację Żydów Wielkopolski, Małopolski, Rusi Czerwonej i Wołynia. Przy Sejmie działał Trybunał, spełniający w odniesieniu do Żydów funkcje zbliżone do tych, jakie dla szlachty wypełniał Trybunał Koronny ${ }^{21}$.

Krótki opis Jarosławia w 1711 r. pozostawił Adam Szathmari Kiraly, dworzanin księcia siedmiogrodzkiego Franciszka II Rakoczego, który po klęsce powstania antyhabsburskiego znalazł schronienie u Sieniawskich ${ }^{22}$.

Jarosław leży na terenie górzystym, w dole płynie rzeka San, miasto otoczone jest głęboką fosą, wokół niej jest mur ceglany, na którym wznosiły się niegdyś baszty ziemne, teraz jednak miasto nie ma żadnej mocy, dawno zaś było silne. Domy też były niegdyś piękne, mimo że nie budowano ich w sposób regularny, jak w innych miastach. Niektóre były z kamienia, inne zaś drewniane $e^{23}$.

${ }^{19}$ Udział dziedziców Jarosławia w rozgrywkach politycznych tego czasu po stronie Augusta II sprowadził na miasto zniszczenia gospodarcze i straty demograficzne, a liczne kontrybucje i rabunki żołnierskie zubożyły mieszczan. Zob. K. Gottfried, Jarosław w XVIII wieku, Jarosław 1933, s. 22-30. Według późniejszej rewizji w 1717 r. było jeszcze w mieście 29 niezabudowanych placów. Zob. J. Motylewicz, Miasta ziemi przemyskiej i sanockiej w drugiej połowie XVII i XVIII wieku, Przemyśl 1993, s. 15.

20 A. Sroka, Świątynie Jarosławia, Jarosław 1998, s. 45-46, 77-78.

21 A. Leszczyński, Sejm Żydów Korony 1623-1764, Warszawa 1994, s. 173-176; S. Grodziski, Znowych badań nad dziejami Waadu - Sejmu Żydów Korony, [w:] Parlament, prawo, ludzie. Studia ofiarowane profesorowi Juliuszowi Bardachowi w sześćdziesięciolecie pracy twórczej, Warszawa 1996, s. 91.

${ }^{22}$ J. Olszewska, Książe węgierski Franciszek Rakoczy II i jego związki z Jarosławiem, „Rocznik Stowarzyszenia Miłośników Jarosławia” (dalej „RSMJ”) T. 9, 1972-1976, s. 59-69.

${ }^{23}$ J. Olszewska, $Z$ diariusza A. Szathmariego dworzanina ks. F. II Rakoczego, „RSMJ” T. 10 , 1983, s. 111. 
Najistotniejsze jednak było to, że Jarosław był w tym czasie miejscem pobytu dworu królewskiego i rady senatu, wcześniej zaś bywał „rad wojennych” i politycznych. Można nawet powiedzieć, że przejął chwilowo funkcje faktycznej stolicy państwa ${ }^{24}$. Miasto było pod specjalną opieką cara Piotra I. W zamian za ochronę swoich majątków przed obcymi wojskami, Sieniawski popierał większość posunięć rosyjskiego monarchy ${ }^{25}$. Biograf hetmana pisze: „Car, choć sam miał kłopotów co niemiara, nie żałował pieniędzy dla hetmana. Wyznaczył mu bowiem rolę jednego ze swoich najwierniejszych stronników w Rzeczypospolitej, twardo się tego trzymał, i jak pokazała przyszłość, nie pomylił się w swych rachubach”26. „Sieniawscy doszli tak wysoko - podkreśla inny historyk - że zdawało się iż po Sasach czeka ich tron, na którym zasiadali Sobieski i Wiśniowiecki”27. Nie ma w tym przesady, gdyż istotnie hetman wielki koronny spodziewał się sięgnąć po koronę dzięki carowi Piotrowi $\mathrm{I}^{28}$.

Zjechał car naprzód do Jarosławia - pisze pamiętnikarz E. Otwinowski - gdzie też i król August przybył w wielkim gronie senatorów polskich; chciał car, i król był tej intencyi, żeby było koniecznie namówić i wprawić w wojnę z Turczynem Rzptą, ale żadną miarą przytomni senatorowie na to pozwolić nie chcieli, ani też mogli, bo decyzya zaczęcia wojny do sejmu należy, a pakta też karłowickie jeszcze były nie wyszły, których expiracya czasu dopiero w r. p. 1724 była $^{29}$.

Wspomniany przez Otwinowskiego zjazd monarchów zaczął się 2 VI 1711 r., rada senatu (senatus consultum) odbyła się zaś w dniach 6-8 VI. Uczestniczyło w niej 3 biskupów, 8 wojewodów, 4 kasztelanów, 4 ministrów, 18 senatorów i 12 plenipotentów ${ }^{30}$. Król August II niechętny był wojnie z Turcją, a i senatorowie jednomyślnie opowiedzieli się przeciwko udziałowi w niej Rzeczypospolitej. 9 VI

${ }^{24} \mathrm{~W} 1704$ r. przeniesiono tu z Łańcuta radę konfederacką (A. Markiewicz, Rady senatorskie Augusta II (1697-1733), Kraków 1988, s. 20, 111, 117), w 1707 r. pod osłoną wojsk rosyjskich zjechali się tu na naradę zwolennicy zdetronizowanego w 1704 r. Augusta II (K. Gottfried, dz. cyt., s. 29).

${ }^{25}$ B. Popiołek, Królowa bez korony. Studium z życia i działalności Elżbiety z Lubomirskich Sieniawskiej ok. 1669-1729, Kraków 1996, s. 80.

${ }^{26}$ S. Leśniewski, Adam Mikołaj Sieniawski herbu Leliwa ok. 1666-1726, [w:] tegoż, Poczet hetmanów polskich i litewskich. XVIII wiek, Warszawa 1992, s. 39.

${ }^{27}$ L. Dębicki, Puławy 1762-183o. T. I, Lwów 1867, s. 11.

28 „Hetman przy pomocy cara spodziewał się być królem” - zapisał E. Otwinowski (dz. cyt., s. 162).

29 Tamże, s. 19. O radzie wspomina również W. F. Rakowski, dz. cyt., s. 150-151.

${ }^{30}$ M. Markiewicz, dz. cyt., s. 21, 31, tab. 1, 53, 61-62, 102, 112, 118. 
podpisano traktat (zwany jarosławskim) wyznaczający każdemu z sojuszników udział w mających się rozpocząć działaniach wojennych. Piotr I wziął na siebie ciężar wojny z Turcją, August II miał zabezpieczyć tyły armii rosyjskiej przed ewentualną napaścią szwedzką ${ }^{31}$. W międzyczasie (w niedzielę 6 VI) uczestnicy narady wzięli udział w ceremonii chrztu dwunastoletniej Zofii Marii, córki hetmana Adama Sieniawskiego i Elżbiety Sieniawskiej. Naoczny świadek uroczystości, cytowany już Szathmari, w swoim diariuszu zapisał:

(...) na drugi dzień pojechaliśmy do Jarosławia, do Hetmana Wielkiego Koronnego Sieniawskiego, który podejmował Jego Wysokość Cara Moskiewskiego, Carową, Jego Wysokość Króla, naszego Pana, Królewicza, Najjaśniejszą Panią, księcia Radziwiłła, hrabiego Berscenyego z małżonką, razem $\mathrm{z}$ innymi książętami, polskimi palatynami, generałami i starostami. Były cztery długie stoły, przy pierwszym zasiadały wyżej wymienione osobistości, przy pozostałych stołach zajęli miejsca panowie szlachta. Tegoż dnia odbyła się ceremonia chrzcin trzynastoletniej córki JW Pani Sieniawskiej. Po uczcie panowie tańczyli do północy, a potem porozjeżdżali się swoimi karetami do kwater ${ }^{32}$.

(...) Ojców chrzestnych było trzech: car Piotr I, król August II Sas i książę siedmiogrodzki Franciszek II Rakoczy (obecny na radzie). Pisze Otwinowski: „wielkie tam ci dostojni chrzestni dali upominki, a najbogatsze ofiarował Rakocy, bo misę wielką złotą, pełną klejnotów bardzo kosztownych (...) chrzciny owe nie w kościele były, ale w polu pod namiotami odprawowały się ${ }^{33}$.

Po podpisaniu traktatu jarosławskiego Piotr I wyruszył (12 VI) w kierunku granicy wołoskiej przeciwko Turkom. Pozostawał natomiast jeszcze jakiś czas w Jarosławiu król August II ze swoim dworem ${ }^{34}$.

${ }^{31}$ J. Feldman, Polska a sprawa wschodnia 1709-1714, Kraków 1926, s. 64-67, 156-157; J. Wimmer, Wojsko Rzeczypospolitej w dobie wojny pótnocnej, Warszawa 1956, s. 385-386; W. A. Serczyk, Piotr I Wielki, Wrocław 1973, s. 151.

32 J. Olszewska, $Z$ diariusza A. Szathmariego, s. 110.

${ }^{33}$ E. Otwinowski, dz. cyt., s. 196.

3420 VI 1711 r. wystawił w Jarosławiu przywilej dla Franciszka Maksymiliana Ossolińskiego na wójtostwo w Drohiczynie. Zob. Katalog dokumentów Biblioteki Zakładu Narodowego im. Ossolińskich. Dokumenty z lat 1270-1979, oprac. I. Lipieński, Wrocław 1999, s. 25-26, nr 58. 
Niedługo potem przybył do Jarosławia Trybunał Koronny, witany uroczyście przez władze miasta oraz profesorów i uczniów kolegiów jezuickich. S. Załęski podaje mylnie, a powtarza za nim K. Gottfried, iż cały Trybunał wziął gremialnie udział w procesji na Boże Ciało, „zadziwiając mieszczan pobożnością"35. Święto to zaś przypadło tego roku na dzień 4 VI. Tymczasem z akt trybunalskich wynika, że jeszcze 25 VI („in crastino festi Nativitatis Sancti Joannis Baptistae”) Trybunał był w Lublinie i używał zwyczajowej formuły: „Działo się w Lublinie” („Actum Lublini in Iudiciis Ordinariis Generalibus Tribunalis Regni”) ${ }^{36}$.

Jak wspomniano wyżej, Trybunał rozpoczął kadencję w Jarosławiu w dniu 13 VII 1711 r., zaś pierwszy ślad działalności jego tutaj zachował się w aktach Z 17 VII tego roku ${ }^{37}$. Z laudum sejmiku wiszeńskiego (o którym będzie niżej) z 6 VII wynika natomiast jasno, że deputaci byli już wtedy w Jarosławiu.

W świetle powyższego można przyjąć, iż Trybunał przybył tu w końcu czerwca lub na początku lipca $1711 \mathrm{r}$. Nie podważając zaś faktu udziału deputatów w procesji, założyć można, iż było to inne święto kościelne przypadające w czerwcu lub lipcu, np. uroczystość św. Apostołów Piotra i Pawła (29 VI) czy Nawiedzenia Najświętszej Marii Panny (3 VII). Okazji do „zadziwiania mieszczan pobożnością" było zresztą wiele, np. 8 IX w święto Narodzenia Najświętszej Marii Panny Trybunał przystąpił in gremio do komunii św. w kościele Matki Boskiej „w Polu”38.

Na początku lipca szlachta województwa ruskiego na sejmiku w Wiszni uchwaliła laudum, w którym wyraziła swoją radość z pobytu Trybunału w Jarosławiu:

A ponieważ ob imminentem pestilentiam w Lublinie translacja prześwietnego trybunału koronnego do Jarosławia jest uczyniona i kadencja onego prędko imminet, przeto województwo nasze obserwując iura humanitatis do powitania J[aśnie] O[świeconego] całego trybunału i podziękowania J[aśnie] O[świeconemu] książęciu I[ego] M[oś]ci Wiśniowieckiemu wojewodzie krakowskiemu marszałkowi trybunału koronnego, J[aśnie] $\mathrm{W}$ [wielmożnemu] I[ego] M[oś]ci księdzu prezydentowi tegoż trybunału ${ }^{39}$

\footnotetext{
${ }^{35}$ S. Załęski, Jezuici w Polsce. T. 4, Kraków 1905, s. 175; K. Gottfried, dz. cyt., s. 31.

36 Świadczy o tym choćby manifestacja złożona tego dnia przez Stanisława Jana Rosochackiego przeciwko Michałowi Sapieże. Zob. APL, Trybunał Koronny Lubelski, sygn. 1493, b.p.

${ }^{37}$ Jest to relacja woźnego sądowego trybunalskiego z doręczenia pozwu datowana „Jaroslaviae (...) feria sexta, post festum Sanctae Margarethae Virginis et Martyriis Proxima”, tamże.

${ }^{38}$ S. Załęski, dz. cyt., s. 1341.

${ }^{39}$ Był nim kanonik gnieźnieński Stanisław Sierakowski, któremu kapituła powierzyła „Z najzupełniejszym zaufaniem w 1711 prezydencyą tego najwyższego w Rzeczypospolitej sądu”.
} 
i wszystkim I[ch] M[oś]ciom pp. deputatom, że w województwie naszym miejsce sobie pro sacrario iustitiae obrać raczyli ${ }^{40}$.

Do powitania deputatów i złożenia podziękowania sejmik wiszeński wybrał delegatów w osobach chorążego przemyskiego Macieja Ustrzyckiego, łowczego i sędziego grodzkiego przemyskiego Franciszka Orzechowskiego oraz cześnika łęczyckiego Antoniego Borzęckiego.

Wróćmy na moment do wydarzeń politycznych. Rosyjska wyprawa antyturecka skończyła się fiaskiem i Piotr I zmuszony był zawrzeć niekorzystny dla siebie pokój (traktat prucki - 26 VII) ${ }^{41}$.

Po owym traktamencie wołoskim ledwie car do siebie przyszedł, owych swoich niedobitków zgłodniałych za Dniepr przez Ukrainę bracławską odesłał, Moskali z Podola i Wołynia ewokował. Sam w niewielkiej kwocie ludzi przyjechał do Jarosławia; tam go trybunał koronny witał, który się tam dla powietrza grassującego w Lublinie sądził ${ }^{42}$.

Czas między posiedzeniami Trybunału urozmaicony bywał przyjęciami, zabawami i festynami. Mieszczanie jarosławscy i okoliczna szlachta za zaszczyt sobie poczytywali możliwość goszczenia deputatów trybunalskich.

15 VIII rozpoczął się największy jarmark jarosławski zwany wielkim, którego bezpieczeństwo (plenam securitatem) zagwarantował car Rosji ${ }^{43}$. Jarmarki jarosławskie w tym czasie nie dorównywały dawniejszym, z poprzedniego stulecia, ale wciąż należały do najważniejszych w Rzeczypospolitej.

Szczególny honor spotkał (28 VIII) zamożnych jarosławian Jana i Mariannę Gruszewiczów, których synowi, Kazimierzowi Barłłomiejowi, sakramentu chrztu udzielił w miejscowej kolegiacie wiceprezydent Trybunału Aleksander Antoni Fredro, późniejszy proboszcz jarosławski (od 1714 r.) i biskup przemyski (od

Zob. J. Korytkowski, Prałaci i kanonicy katedry metropolitalnej gnieźnieńskiej od roku 100 a az do dni naszych. Podtug źródeł archiwalnych. T. 3, Gniezno 1883, s. 502.

40 Akta Grodzkie i Ziemskie. Cz. 22, Lauda sejmikowe, T. 3, Lauda wiszneńskie 1673-1732, oprac. A. Prochaska, Lwów 1914, nr 187 - Laudum sejmiku wiszeńskiego 6 VII 1711 r.

${ }^{41}$ W. A. Serczyk, dz. cyt., s. 154.

${ }^{42}$ E. Otwinowski, dz. cyt., s. 201.

${ }^{43}$ Stosowny dokument wystawił 18 VII komisarz carski Dąbrowicz. Zob. M. Proksa, Przewodnik po zespole Akta miasta Jarosławia, Przemyśl 1994, s. 67, nr 24. 
1724 r.) ${ }^{44}$. Mało tego, dziecko do chrztu trzymał Piotr I, a matką chrzestną była Elżbieta Sieniawska. Drugą parę chrzestnych tworzyli generał major wojsk rosyjskich Antoni z Gęzowa Goschau i „Aurora Spiglowa”"

Mieszkańcom Jarosławia car dał się poznać od najlepszej strony. W kronice klasztoru bernardynów w pobliskim Przeworsku nieznany nam autor zapisał: „Nikt się przed carem darmo nie poskarżył, z najmniejszym rad gadał, na biesiady mieszczan uczęszczał, w obozie naywięcey przebywał, i sam każdemu sprawiedliwość czyni»"46.

Piotr I gościł u Sieniawskich do października 1711 r., przerywając swój pobyt w Jarosławiu krótkimi wyjazdami, jak np. w końcu sierpnia do Gdańska, podczas którego carowi towarzyszył książę Rakoczy ${ }^{47}$.

Gdzie zbierali się deputaci? W miastach trybunalskich Piotrkowie i Lublinie Trybunał sądził w ratuszu. Czy było tak i w Jarosławiu, trudno dociec. Jako prawdopodobne miejsce odbywania się sesji sądowych można przyjąć również kolegium jezuitów św. Jana, posiadające odpowiednie ku temu pomieszczenia ${ }^{48}$. Pewne jest natomiast, że z gościny jezuitów korzystał marszałek Trybunału, książę Janusz Wiśniowiecki ${ }^{49}$.

Gdy kadencja Trybunału w Jarosławiu przedłużała się ponad miarę, zaniepokojona tym szlachta lubelska, zgromadzona na sejmiku w Bronowicach pod Lublinem (też z powodu zarazy), uchwaliła 20 VIII laudum, w którym domagała się powrotu „swojego" sądu.

Trybunał Koronny w mieście województwa naszego stołecznym Lublinie czytamy w dokumencie - od początku założenia do sądzenia się złożony, konstytucjami utwierdzony, do Jarosławia extra territorium przeniesiony jest, dlaczego upraszamy imć pana Marszałka koła naszego, aby imieniem całego województwa zaniósł ad acta manifest o nienależyte z województwa trybunału przeniesienie.

${ }^{44}$ Jako wiceprezydent wielokrotnie zastępował w latach 1708-1711 prezydenta, zaś później (1714-1716) sam był prezydentem Trybunału. Zob. J. Kwolek, Fredro Aleksander Antoni (1874-1734), [w:] Polski Słownik Biograficzny. T. 7, Kraków 1948, s. 104-105.

${ }^{45}$ F. Siarczyński, dz. cyt., s. 111. Zapewne chodzi tu o byłą metresę Augusta II, brankę turecką Fatimę, znaną pod nazwiskiem Maria Aurora vel Maria Anna von Spiegel. Zob. J. Staszewski, August II Mocny, Wrocław 1998, s. 45, 53, 86.

${ }^{46}$ F. Siarczyński, dz. cyt., s. 111-112.

47 B. Popiołek, dz. cyt., s. 8o-82.

${ }^{48}$ Tu odbyła się wzmiankowana narada w 1707 r. Zob. K. Gottfried, dz. cyt., s. 29.

49 S. Załęski, dz. cyt., s. 175. 
Marszałek lubelskiego „koła rycerskiego” Felicjan z Targowiska Gałęzowski zobowiązany został również do wysłania stosownych listów do „marszałka i całego Trybunału", prymasa oraz dygnitarzy koronnych ${ }^{50}$. Obawy szlachty lubelskiej nie były zupełnie bezpodstawne, bowiem - jak pisze F. Siarczyński - „odezwały się w ówczas sprawiedliwe wielu obywatelów żądania, aby ruski trybunał, oddzielony od małopolskiego, stale i nazawsze w Jarosławiu był sądzony" ${ }^{51}$. Żądania takie nie były żadnym novum. Pierwsze projekty zmian w strukturze Trybunału, zgłaszane przez szlachtę czerwonoruską na sejmikach w Haliczu i Sądowej Wiszni, pojawiły się już pod koniec XVI w. (1592 r.), z tym że myślano o Lwowie jako miejscu odbywania się trzeciej kadencji sądu najwyższego dla szlachty $\mathrm{z}$ województw południowo-wschodnich ${ }^{52}$.

Kadencja lubelska Trybunału Koronnego w Jarosławiu zakończyła się zgodnie z konstytucją z 1676 r. przed Bożym Narodzeniem (19 XII 1711 r.) ${ }^{53}$. Pobyt Trybunału Koronnego przez kilka miesięcy 1711 r. w Jarosławiu przyniósł mieszczanom wymierne korzyści. W czasie trwania kadencji wzrosło zapotrzebowanie na różnorodne towary i wyroby rzemieślnicze, żywność i paszę dla koni, zwiększeniu uległy dochody w gospodach i zajazdach. Dla właścicieli Jarosławia możliwość goszczenia u siebie najwyższej instytucji sądowej w państwie miała przyczynić się do powiększenia prestiżu rodu i załatwienia spraw majątkowych. Duża w tym zasługa Elżbiety Sieniawskiej. Ta wielce wpływowa i energiczna dama, jak mało która z przedstawicielek magnaterii koronnej, potrafiła zadbać o dobro rodu i jego fortunę. Swój pobyt w dobrach jarosławskich w $1711 \mathrm{r}$. wykorzystywała do uporządkowania kwestii majątkowych, których wiele nagromadziło się w sądach. Między innymi w Trybunale Koronnym toczył się jej proces z Konstancją z Potockich, wdową po podkanclerzym litewskim Stanisławie Antonim Szczuce (zm. 1710 r.), o dobra Toporów w ziemi lwowskiej, zakończony wygraną w 1713 r. Dzięki pieniądzom i prezentom hojnie rozdzielanym między deputatów potrafiła zapewnić

${ }^{50} \mathrm{Kgl}$, Relacje, sygn. 199, s. 486-487.

${ }^{51}$ F. Siarczyński, dz. cyt., s. 112.

${ }^{52}$ Sejmiki wiszeński i halicki postulowały utworzenie osobnej kadencji Trybunału we Lwowie dla województw: ruskiego, bełskiego, wołyńskiego, kijowskiego, podolskiego i czernihowskiego również później (1720, 1723, 1724, 1732 i 1736 r.). Ostatecznie zostało to zrealizowane dopiero na sejmie konwokacyjnym w 1764 r., gdy ustanowiono odrębny Trybunał Lwowski. Zob. J. Michalski, Reforma sądownictwa na sejmie konwokacyjnym w 1764 roku, [w:] Między wielka politykg a szlacheckim partykularzem. Studia z dziejów nowożytnej Polski i Europy ku czci Profesora Jacka Staszewskiego, Torun 1993, s. 308-310; W. Bednaruk, dz. cyt., s. 102-105.

${ }^{53}$ APL, A. Myśliwiec, Trybunał Koronny Lubelski [Iudicium Ordinarium Generale Tribunalis Regi Lublinensis] 1579-1794 [1796-1811], Wstęp i inwentarz, Lublin 2008, niepublikowany, s. XII. 
sobie przyjaźń niemal całego Trybunału ${ }^{54}$. Koszty takiego „zjednywania” sędziów były spore, np. w 1713 r. gratyfikacja dla marszałka Trybunału wyniosła ją 500 czerwonych złotych, „,bo tak dała wojewodzina podlaska przy okazji swojego procesu (...). Deputatom od dekretu dała 150 czerw. zł, na końcu miano wynagrodzić deputatów, których tu siła, bo 18, szable złote i insze pstre" ${ }^{\text {55 }}$. Funkcję deputata trybunalskiego pełniło się bezpłatnie, ale tylko teoretycznie, faktycznie przynosiła ona znaczne dochody, nie tyle z tzw. skrzynki, co nieoficjalnie. Choć deputatom surowo zakazywano brania jakichkolwiek pieniędzy czy podarunków, to jednak rzadko tego przestrzegano, a tak zwane poczęstunki w zamożnych domach traktowano jako rzecz zupełnie normalną. Ponadto granica pomiędzy poczęstunkiem czy wziątkiem a zwyczajową należną sędziemu opłatą była dość płynna. Szlachta uważała, że za służbę Rzeczypospolitej należy się godziwe wynagrodzenie, a kto płaci, to już rzecz drugorzędna ${ }^{56}$.

Owocem jarosławskiej kadencji Trybunału Koronnego (łącznie z początkiem lubelskim) były: 1 księga czystopisowa (inducta) zapisów (kart 945), 2 księgi brudnopisowe zapisów (kart 555 i 692) „obejmujące w sobie tego samego rodzaju, jak powyższe inductarum", 2 księgi wyroków (decretorum) (kart 1508 i 1549) i 8 ksiąg wpisów spraw - 1 remissarum (odesłanych na następną sesję), 1 województwa ruskiego, 1 Ordynacji Zamojskiej, 2 skazanych na wypędzenie (bannitionum), 2 taktowych, czyli pozwów ustnych, gdy woźny sam doprowadzał pozwanego do sądu (terminorum tactorum) i 1 uwięzionych (incarceratorum ${ }^{57}$. Z powodu zniszczenia powyższych i innych akt trybunalskich niemożliwe jest dziś ustalenie, jakie sprawy toczyły się przed Trybunałem Koronnym w Jarosławiu, ani ile ich było.

Po utracie przez Rzeczpospolitą niepodległości akta lubelskiej kadencji Trybunału przechowywano początkowo $\mathrm{w}$ archiwum sądowym, mieszczącym się w refektarzu klasztoru Dominikanów w Lublinie. W 1811 r. przeniesiono je do klasztoru Bernardynów, a w 1827 r. do nowo powstałego Archiwum Akt Dawnych w Lublinie. W latach 1836-1840 akta zostały przekazane do Archiwum Głównego Akt Dawnych w Warszawie, gdzie w czasie powstania warszawskiego w $1944 \mathrm{r}$.

54 B. Popiołek, dz. cyt., s. 88-95.

55 Tamże, s. 91.

56 M. Borucki, Temida staropolska. Szkice z dziejów sądownictwa Polski szlacheckiej, Warszawa 1979, s. 55-56; J. Tazbir, Korupcje, posuly, kubany i wziątki, [w:] Parlament, prawo, ludzie, s. 300-305.

57 APL, P. Zagrobski, Konsygnacja akt dawnych polskich z całego województwa w mieście Lublinie skoncentrowanych $w$ roku 1832 uformowana, rkps, s. 58-99, 101-123. 
uległy całkowitemu zniszczeniu ${ }^{58}$. W Lublinie pozostały jednak tzw. dissoluta. One to wraz z księgami grodzkimi i ziemskimi w 1887 r. na polecenie władz rosyjskich zostały zabrane do Archiwum Centralnego w Wilnie, gdzie pozostawały do $1918 \mathrm{r}$. Wróciły w 1919 r. do nowo powstałego Archiwum Państwowego w Lublinie. Dziś tworzą główny trzon zespołu archiwalnego: Trybunał Koronny Lubelski. Z ksiąg trybunalskich ocalały: księga dekretów z 1591 r., wcześniej pomyłkowo włączona do ksiąg grodzkich lubelskich, oraz fragmenty trzech innych ksiąg z lat 1623-1793, zachowanych w zespole ksiąg ziemskich lubelskich ${ }^{59}$.

Pośród pozostałości aktowej Trybunału Koronnego Lubelskiego zachowało się kilka luźnych dokumentów spisanych in Iudiciis Ordinariis Generalibus Tribunaliis Regni, ob grassantem Lublini pestilentiam Jaroslaviam translati (między 17 VII a 2 XI 1711 r.), świadectwo jarosławskiego epizodu dziejów Trybunału Koronnego w Lublinie.

W Jarosławiu ten fakt upamiętniono nazwaniem jednej ze staromiejskich uliczek mianem Trybunalskiej ${ }^{60}$.

\section{Summary}

\section{The Jarosław Episode in the History of the Crown Tribunal in Lublin in 1711}

The Crown Tribunal established in 1578 was the supreme court for the nobility in the Pre-partition Commonwealth. Lublin was the seat of the Tribunal for over 200 years and only once in its history it sat in another town: in Jarosław. In the twelfth year of the Great Northern War (1700-1721) in April 1711 the ceremonial beginning of the new term of the Crown Tribunal in Lublin took place. The short period of relative peace in the town was interrupted by the outbreak of plague. The Tribunal deputies accepted the invitation by the owners of the town of Jarosław, Great Crown Hetman Adam Mikołaj Sieniawski and his wife Elżbieta nee Lubomirska as well as the Ostrog estate entailer and Sandomierz starost Aleksander Dominik Lubomirski, to continue the interrupted session there. At that time the town

\footnotetext{
58 A. Stebelski, Dzieje zniszczenia Archiwum Głównego Akt Dawnych, [w:] Straty archiwów i bibliotek warszawskich $w$ zakresie rękopiśmiennych źródeł historycznych. T. 1, Warszawa 1957, s. 26-27; A. Wolff, Księgi Trybunału Koronnego, 1578-1794, [w:] Straty archiwów, s. 128-131.

${ }^{59}$ A. Myśliwiec, dz. cyt., s. XIV-XXVII.

${ }^{60}$ Uchwała z 1892 r., Muzeum w Jarosławiu, Ksiega Uchwał Rady Komunalnej 1891-1893.
} 